\title{
Effects of oil palm and human presence on activity patterns of terrestrial mammals in the Colombian Llanos
}

\author{
Lain E. Pardo ${ }^{1,2,3}$ (D) William Edwards ${ }^{1} \cdot$ Mason J. Campbell ${ }^{1}$ - Bibiana Gómez-Valencia ${ }^{2,4}$. \\ Gopalasamy Reuben Clements ${ }^{5,6}$. William F. Laurance ${ }^{1}$
}

Received: 19 January 2021 / Accepted: 23 June 2021 / Published online: 16 July 2021

(c) The Author(s) 2021

\begin{abstract}
The ability of animals to adjust their behaviour can influence how they respond to environmental changes and human presence. We quantified activity patterns of terrestrial mammals in oil palm plantations and native riparian forest in Colombia to determine if species exhibited behavioural changes depending on the type of habitat and the presence of humans. Despite the large sampling effort (12,403 camera-days), we were only able to examine the activity patterns of ten species in riparian forests and seven species in oil palm plantations, with four species (capybara, giant anteater, lesser anteater and common opossum) being represented by enough records (i.e. $n>20$ ) in both oil palm and forest to allow robust comparisons. Only capybaras showed an apparent change in activity patterns between oil palm plantations and riparian forests, shifting from being crepuscular in forest to predominantly nocturnal inside oil palm plantations. Further, capybaras, giant anteaters and white-tailed deer appeared to modify their activities to avoid human presence inside oil palm plantations by increasing nocturnality (temporal overlap $\widehat{\Delta}$ ranged from 0.13 to 0.36 ), whereas jaguarundi had high overlap with human activities $[\hat{\Delta}$ $=0.85(0.61-0.90)]$. Species pair-wise analysis within oil palm revealed evidence for temporal segregation between species occupying the same trophic position (e.g. foxes and jaguarundi), whereas some predators and their prey (e.g. ocelots and armadillos) had high overlaps in temporal activity patterns as might be expected. Our findings shed light on the potential behavioural adaptation of mammals to anthropogenic landscapes, a feature not captured in traditional studies that focus on measures such as species richness or abundance.
\end{abstract}

Keywords Agroecosystem $\cdot$ Anteaters $\cdot$ Circadian rhythms $\cdot$ Diel activity $\cdot$ Mesopredators $\cdot$ Temporal overlap

Handling editor: Adriano Martinoli.

Lain E. Pardo

lepardov@gmail.com

1 Centre for Tropical Environmental and Sustainability Science, College of Science and Engineering, James Cook University, Cairns, QLD 4878, Australia

2 Grupo de Conservación y Manejo de Vida Silvestre, Universidad Nacional de Colombia, Bogotá D.C., Colombia

3 Department of Nature Conservation Management, Faculty of Science, Nelson Mandela University, Office 47, Research Building, Madiva Drive, George 6530, South Africa

4 Instituto de Investigación de Recursos Biológicos Alexander Von Humboldt, Bogotá D.C., Colombia

5 Department of Biological Sciences, Sunway University, 47500 Bandar Sunway, Selangor, Malaysia

6 Rimba, Jalan Kiara 5, 50480 Kuala Lumpur, Malaysia

\section{Introduction}

The capacity of species to adapt to human activities will determine their chances of survival in the face of anthropogenic habitat change (Sih et al. 2011; Wong and Candolin 2015). Typically, responses to habitat alteration are analysed through metrics such as species diversity and animal abundance (e.g. Rovero et al. 2014; Wearn et al. 2017), along with more recent estimates of occupancy (e.g. Pardo et al. 2016; Yue et al. 2015). These are measures based on sample counts, or proportional contributions of individual species to overall individual counts, which are then assessed against habitat variables such as area or type of land cover/use. However, behavioural modifications (e.g. foraging periods, food preferences) also play an important role in the resilience of species in increasing human-dominated landscapes (Gaynor et al. 2018). Therefore, the study of activity patterns (i.e. sequences of daily routines) can also help us to understand 
the influence of human presence on mammal assemblages and their capacity to persist in human-dominated landscapes.

Activity patterns are shaped by natural factors and physiological requirements of individual species, including requirements of thermoregulation, seasonal changes in temperature and moisture as well as biotic interactions such as competition and predator pressure (Halle 2006). Behavioural responses must, by their nature, allow species to exist across a range of conditions and are thus flexible to the actual state of the environment or human-driven process (Halle 2000). For example, Gaynor et al. (2018) conducted a meta-analysis and found that mammals are becoming more nocturnal in response to human disturbances. Evidence suggests that species can modify their behaviour depending on hunting pressures (Di Bitetti et al. 2008). Further, some mammal species can modify their activity patterns depending on the habitat type, presence of human activity, or size of patches. For example, in the Peruvian Amazon, the activity patterns of some bats change between land cover types such as agriculture and forest types (Presley et al. 2009). Similarly, in the Brazilian Amazon, nine-banded armadillos (Dasypus novemcinctus) modify their activity patterns depending on the size of the fragments in which they occur, having strictly nocturnal activity in big fragments ( $>1000 \mathrm{ha}$ ), but a more cathemeral pattern in smaller ones (Norris et al. 2010).

Oil palm is one of the biggest threats to biodiversity in Southeast Asia (Azhar et al. 2014; Fitzherbert et al. 2008). Although the production of oil palm in Colombia is not the primary cause of deforestation (Furumo and Aide 2017; Pardo and Ocampo-Peñuela 2019), it is one of the most rapidly expanding crops in natural or seminatural ecosystems (Reviewed by Pardo et al. 2015). Up to 2018, there was $~ 540,000$ ha oil palm officially registered (Fedepalma 2019). Only recently have the effects of oil palm production on Neotropical fauna begun to be evaluated. For example, Gilroy et al. (2015), compared the diversity of ants, birds, herpetofauna, and dung beetles in the Llanos region (eastern plains) and found that diversity of the three first taxa was higher in the forest than in oil palm plantations. Similar results have been reported for other taxonomic groups such as birds (e.g.López-Ricaurte et al. 2017; Prescott et al. 2016) and mammals (e.g. Pardo et al. 2018a, b; Pardo and Payán 2015). These studies have been based on the traditional approach of linking metrics of diversity to landscape variables and analyses that considers species identities in broad functional groups. To our knowledge, however, no previous study has evaluated activity patterns of medium and large-sized mammalian assemblages in human-dominated landscapes in Colombia.

In the Neotropics, the study of activity patterns has increased in recent years, especially in countries such as Peru, Bolivia, and Brazil (e.g. Di Bitetti et al. 2006; Foster et al. 2013; Gómez et al. 2005; Maffei et al. 2005;
Oliveira-Santos et al. 2008; among others). However, very few of those studies quantify the temporal relationships between species in the community or between habitats (e.g. Presley et al. 2009). This is important information as the study of activity patterns can be used as indicators of how species use available resources, potential predator-prey relationships, competition/coexistence between species, foraging effort (time and energy), and predation risk (e.g. Di Bitetti et al. 2010; Durant 1998; Weckel et al. 2006; Wong and Candolin 2015). The effects of human landscape modification on behaviour can be analysed by comparing activity patterns overlap between two or more ecosystems, or between pairs of species within a single habitat (i.e. between species interaction) (Ridout and Linkie 2009). In human-dominated landscapes, such as plantations, comparisons between human and animal species can reveal potential co-ocurrence between humans and animals depending on animals' flexibility to modify their daily routines. Therefore, studies of overlaps between activity patterns will help to respond if the tolerance shown by some mammal species to oil palm is also facilitated by changing periods of activity to avoid human disturbances.

Colombia is ranked among the five most diverse countries in the world for mammals with 518 species recorded to date (Ramírez-Cháves et al. 2016). Nevertheless, little is known on the natural history of terrestrial mammals, and much less is known about activity patterns (e.g. Caceres-Martínez et al. 2016; González-Maya et al. 2009; Muñoz et al. 2002). To our knowledge, only two studies have assessed temporal overlap between species in Colombia (i.e. González-Maya et al. 2015; Ramírez-Mejía and Sánchez 2016). The lack of mammal studies is particularly evident along riparian or gallery forest (Díaz-Pulido et al. 2017), which are forest strips bordering rivers or "caños" in the Llanos region, located in the Orinoco Basin of Colombia (IDEAM et al. 2007). This type of forest is one of the most important remnant ecosystems in the Llanos due to its existence as a series of wildlife refuges and as corridors across natural savannas or mosaics of agricultural landscapes (Lasso et al. 2011; Pardo et al. 2018a).

Since the study of animal behaviour in human-dominated landscapes is limited, our understanding of the ability of animals to adjust their behaviour in response to human activities (i.e. harvesting related activities) is also poorly understood. The objective of this study was, therefore, to elucidate whether oil palm and human activities affect the activity patterns of terrestrial mammal species in oil palm-dominated landscapes in Colombia. For this, we quantified the overlap between periods of animal activity using the records from a large camera trapping in the Colombian Llanos. Specifically, we address the following questions: (1) Do terrestrial mammals modify their activity patterns between oil palm and riparian forest habitats? (2) Do terrestrial mammals 
inside oil palm avoid times of high human activity? (3) How do species-specific temporal interactions among terrestrial mammals differ between these two habitats? Since oil palm is a relative recent land use in the area, we did not expect to find important differences in activity patterns of most species between forest and plantation/ however, we hypothesized that human presence inside plantations would slightly change the daily patterns due to perceive risk and disturbance (e.g. noise, traffic, etc.). This study complements a series of studies conducted in the study area (e.g. Pardo et al. 2018b, 2019).

\section{Methods}

\section{Study area}

The study area was located in the Colombian Llanos Orientales region (here after Llanos) and included rural areas of the towns of Restrepo, Cumaral, Cabuyaro, Acacias, Castilla la Nueva and San Carlos de Guaroa. All towns are situated in the department of Meta, between 194 and 394 m a.s.l. Yearly average daily temperature range from 20 to $33{ }^{\circ} \mathrm{C}$, with a bimodal rainfall pattern (i.e. one dry season and one wet season per year). This area has a long history of landscape modification by human activity and is currently dominated by oil palm plantations, which mostly consist of large-scale production (industrialized). Other activities include mostly cattle grazing and to a lesser extent, rice cultivation. The remnant natural ecosystem in the region is predominantly secondary riparian forest strips (gallery forest) varying in size and age, some of which experience seasonal inundation. None of the plantations were RSPO certified, but hunting was explicitly prohibited in most of these sites. For a figure of study area see Pardo et al (2018a, b).

\section{Survey design}

We sampled 56 sites, 33 inside oil palm plantations, and 23 within riparian forest covering an area of approximately $2000 \mathrm{~km}^{2}$. Sites (sampling unit) were separated by at least $2 \mathrm{~km}$ to maintain sample independence. This site placement criterion exceeds the minimum recommended inter-site distance for inventories of terrestrial mammals in the Neotropics (e.g. Silveira et al. 2003; Team Network 2008; Tobler et al. 2008). Furthermore, previous research in the region suggests that this inter-site distance corresponds to the average diameter of home ranges for the common mammal species occurring in the study area (i.e. Ferrer et al. 2009; Pardo and Payán 2015). Surveys were conducted during the dry season between September 2014 and January 2016. We sampled plantations that were at least 10 years old (i.e. planted no later than 2006). Due to the limited number of cameras, sites were not surveyed simultaneously but progressively as cameras were retrieved and, therefore, available to be deployed in other sites.

\section{Camera trapping}

We used seven Reconyx HC500 HyperfireTM digital cameras at each site (sampling unit) to detect mammals. Cameras were placed along a $1.5-\mathrm{km}$ transect with the first camera randomly located and the remaining cameras set every $250 \mathrm{~m}$. This protocol was used to increase survey success per site (Pardo et al. in preparation), compared to the traditional mammal research approach of one camera per site (Burton et al. 2015). Where feasible, cameras inside riparian forests (hereafter referred to as forest) were placed along animal paths or facing small gaps in the vegetation to maximize capture success. To increase coverage and capture probabilities of cameras within regularly arrayed oil palm trees within oil palm plantations (hereafter referred to as oil palm), cameras were positioned in a zigzag arrangement. Most cameras were positioned facing the harvesting path where animals are most likely to move and where vegetation is usually low. This allows for the correct operation of the camera and therefore maximize the detection probability.

We fixed all cameras to trees (including oil palm trees when possible) or wooden poles with a steel cable and were located at approximately one-two metre from the potential path of animals and $25-30 \mathrm{~cm}$ height depending on the terrain. Cameras were configured with the following criteria: high sensibility sensor, one-second interval between consecutive pictures (three per trigger), no delay or a quiet period between triggers and were active for 30 to 40 days without baiting. We filtered the detection of the species (animal photos) using a 30-min independence criteria between consecutive photos of the same species (O'Brien et al. 2003).

\section{Activity patterns}

To estimate daily activity patterns of terrestrial mammals and determine how they differ between oil palm and riparian forest, we followed the approach developed by Ridout and Linkie (2009). In this approach, species activity periods are estimated using circular Kernel probability density function, and similarities between two activity patterns (e.g. between different habitats, or between species) are quantified by the coefficient of overlapping $(\widehat{\Delta})$. This coefficient ranges from zero (i.e. no overlap) when two activities patterns are different or segregate from each other to one if they are completely similar (i.e. complete overlap). Since this coefficient can be influenced by sample size, we used a smoothing parameter of $\widehat{\Delta}_{4}$ for species with more than 75 records and $\widehat{\Delta}_{1}$ for those with less than 50 (Ridout and Linkie 2009). 
We included only those species with more than 20 independent records to ensure the analysis was robust and to avoid making inferences about species where limited data were available. Therefore, in cases where the same species had more than 20 records in either of the two habitats, but less than this in the other, the estimated activity pattern is shown for the habitat with more than the minimum records, and no overlap coefficient was reported because of its high imprecise estimations. We used the same framework to evaluate the influence of human activity inside oil palm plantations (for species with high detections during day times) and to evaluate interspecific temporal relationships for all possible pair-wise species comparisons within each land use type. We defined human activity as any activity where humans are present including cars, harvesting, cleaning, walking, etc., derived from the camera photos inside the plantations. All analyses were conducted in the R package "overlap" (Meredith and Ridout 2017; R Development Core Team 2014).

We classified all species into four broad categories of activity period (modified from van Schaik and Griffiths
1996) as per visual examination of the estimated Kernel probability density plots. As such, species were considered diurnal when the density (area under the curve) where maximum between 0600 and $1800 \mathrm{~h}$, nocturnal when between 1800 and $0600 \mathrm{~h}$ and species were classified as crepuscular when the peak of density plots was between 0500 and $0600 \mathrm{~h}$ (dawn) and/or 1700-1800 h (dusk) The final category, cathemeral (see Halle 2006), was used when a species showed no clear preference for any of the three previous categories, demonstrated via the distribution of activity over the $24-\mathrm{h}$ showing no clear pattern of peaks.

\section{Results}

We recorded 2515 independent photographs from 23 medium and large-sized terrestrial mammals across the study area, from which 1947 were in forest and 568 in oil palm plantations (Table 1). Further, we recorded 2344 instances of human activity in palm plantations, and 78
Table 1 Independent detection (photographs) of the 24 mammalian species detected inside oil palm plantations and riparian forest across the Llanos region, Colombia

\begin{tabular}{|c|c|c|c|}
\hline Common name & Scientific name & Riparian forest & $\begin{array}{l}\text { Oil palm } \\
\text { planta- } \\
\text { tion }\end{array}$ \\
\hline Giant anteater & Myrmecophaga tridactyla & 116 & 123 \\
\hline Lesser anteater & Tamandua tetradactyla & 65 & 39 \\
\hline Nine-banded armadillo & Dasypus novemcinctus & 119 & 4 \\
\hline Naked tailed armadillo & Cabassous unicinctus & 25 & 0 \\
\hline Fox & Cerdocyon thous & 14 & 226 \\
\hline Jaguarundi & Puma yagouaroundi & 6 & 20 \\
\hline Ocelot & Leopardus pardalis & 57 & 15 \\
\hline Puma & Puma concolor & 2 & 1 \\
\hline Greater grison & Galictis vittata & 2 & 1 \\
\hline Tayra & Eira barbara & 2 & 0 \\
\hline Crab eating raccoon & Procyon cancrivorus & 6 & 16 \\
\hline Coati & Nasua nasua & 15 & 0 \\
\hline White -tailed deer & Odocoileus cariacou & 8 & 22 \\
\hline Red deer & Mazama sp. & 0 & 2 \\
\hline Collared peccary & Pecari tajacu & 1 & 1 \\
\hline Spiny rat & Proechimys spp. & 182 & 3 \\
\hline Mice & $\mathrm{nn}$ & 0 & 2 \\
\hline Agouti & Dasyprocta fuliginosa & 425 & 0 \\
\hline Paca & Cuniculus paca & 469 & 1 \\
\hline Capybara & Hydrochaerus hydrochaeris & 99 & 29 \\
\hline Coendu & Coendu spp. & 1 & 0 \\
\hline Squirrel & Ssciurus spp. & 44 & 0 \\
\hline Common opossum & Didelphis marsupialis & 288 & 63 \\
\hline Four eyed oppossum & Philander opossum & 1 & 0 \\
\hline Total records & & 1947 & 568 \\
\hline
\end{tabular}

Independency criteria $=30$ min between consecutive photographs of the same species $n n$ species not identifiable by camera trap 
inside the forest (Table 1). (For discussion about species richness and composition refer to Pardo et al. 2018a, b).

Overall, capture records of individual species (sample size) were low, especially for most species inside oil palm (see Pardo et al. 2018a), which limited the comparison between habitat types (oil palm and forests) for most of the 17 shared species (Table 1). We detected eight carnivores in the landscape, seven of which were mesopredators (fox, jaguarundi, ocelot, greater grison, crab-eating raccoon, coati, tayra; for scientific names see Table 1), and only one top predator (puma). However, the majority were rare and only two species were recorded in sufficient numbers ( $>20$ independent photographs) inside oil palm for analysis (jaguarundi and fox) and only one species (the ocelot) resulted in enough detections inside the forest.
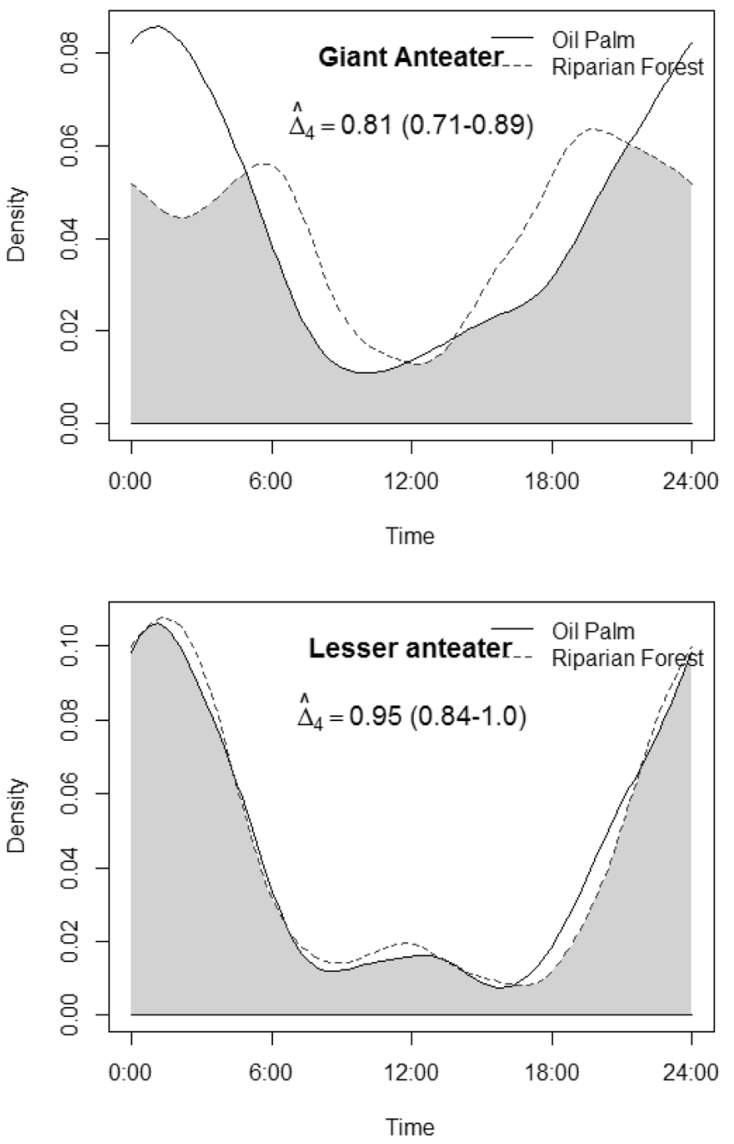

Fig. 1 Activity patterns and overlap coefficient estimate $(\widehat{\Delta})$ for most common shared species between riparian forest and oil palm plantations in the Llanos region of Colombia. The shaded region denotes the activity overlap of each species between the two land cover types,

\section{Activity patterns within habitats}

\section{Riparian forest}

In the riparian forest, only 10 out of 23 species had sufficient records $(n>20)$ to reliably estimate their activity patterns (Table 1), two of which were found exclusively in the forest (naked tailed armadillo and agouti). Ocelots, lesser anteaters (Tamandua tetradactyla), capybaras (Hydrochaerus hydrochaeris), and common opossums (Didelphis marsupialis) showed greater activity during night times, with a low density of probability during the daytime (Figs. 1,2). However, capybaras activity was clearly narrowed towards crepuscular times (particularly at dusk). Giant anteaters (Myrmecophaga tridactyla) were relatively cathemeral with a concentration of activity during crepuscular times, and a tendency to be inactive at midday (Figs. 1,2). Nine-banded armadillos (Dasypus novemcinctus), naked-tailed armadillos (Cabassous unicinctus), pacas (Cuniculus paca) and the spiny
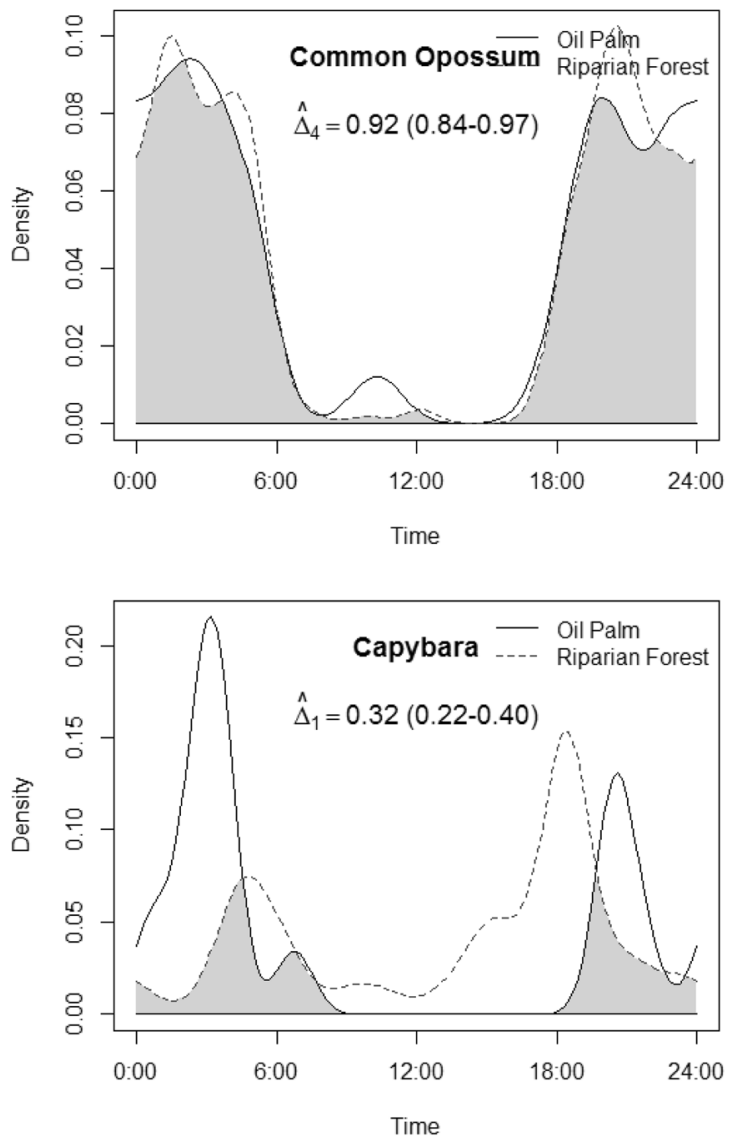

based on Kernel density. $\widehat{\Delta}$ ranges from 0 to 1 , being 1 complete overlapping, parenthesis indicates the $95 \%$ confidence intervals. Only species with minimum 20 records in both habitats were analysed (for sample sizes refer to Table 1) 


\section{(a) Oil palm plantation}
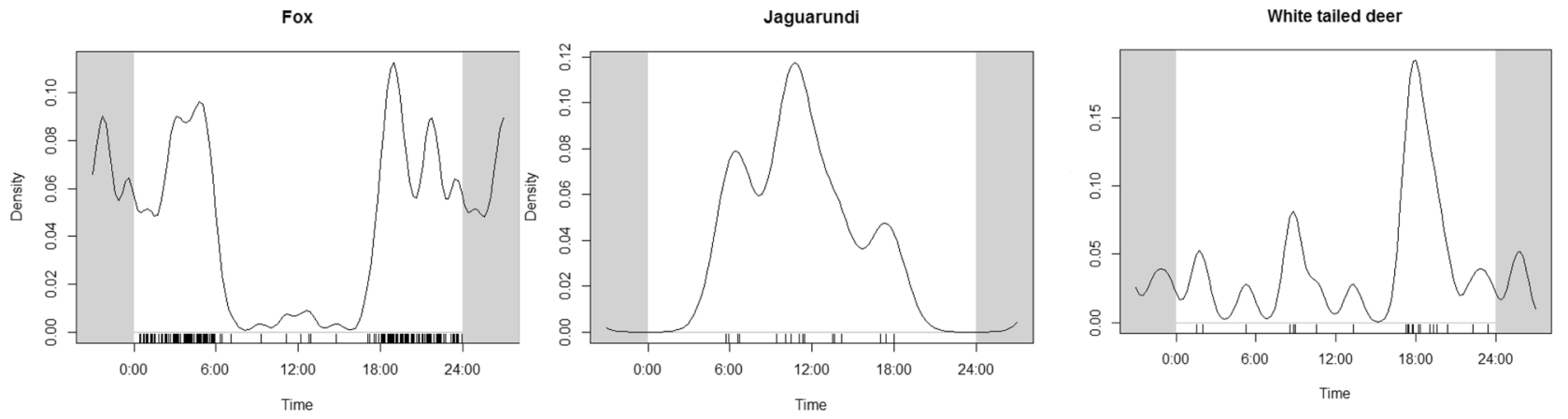

\section{(b) Riparian Forest}
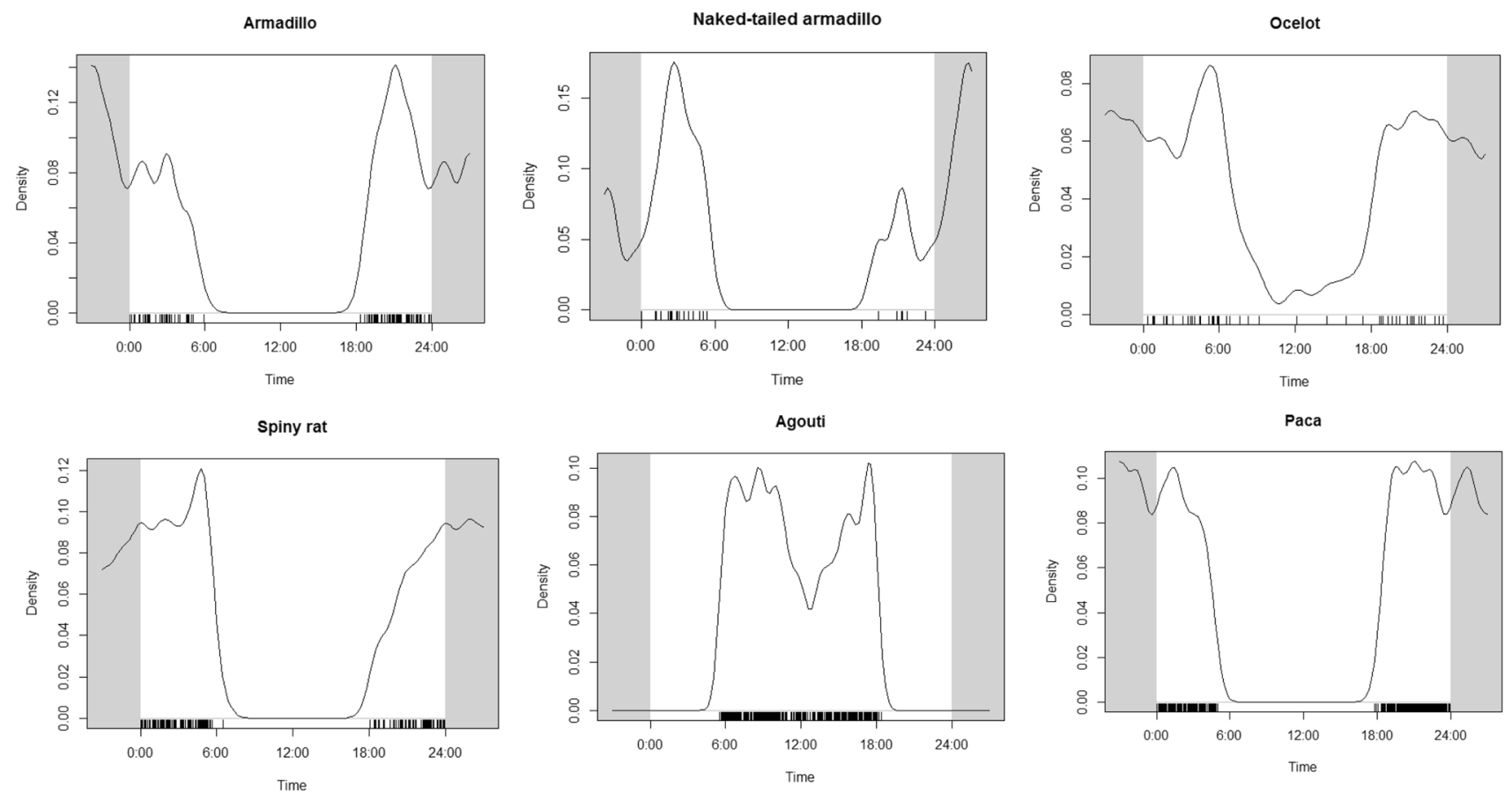

Fig. 2 Activity patterns estimates for selected species in oil palm plantations (a) and riparian forest (b) in the Llanos region of Colombia. The graphs were constructed using Kernel density functions for species with more than 20 records in any of the habitats. For species with robust data for both habitats refer to Fig. 1

contrary to the forest where they were also active in late afternoon or crepuscular times. The remaining species showed a nocturnal habit with few detections during the daytime (e.g. fox, white-tailed deer). White-tailed deer and jaguarundi had more records in oil palm plantations than inside forests, with white-tailed deer showing a tendency to cathemerality, but with a clear narrow peak of activity around $1800 \mathrm{~h}$ (crepuscular), while jaguarundi were strictly diurnal. However, jaguarundi showed a preference for the morning with a peak of activity around midday, after which activities decline notably (Fig. 2). Inside oil palm, giant anteater cathemerality was less evident compared to the forest 
Table 2 Overlapping coefficient estimate $(\widehat{\Delta})$ based on Kernel density function estimates between selected species pairs inside riparian forest and corresponding activity period categories across oil palm dominated landscapes in the Llanos region, Colombia.

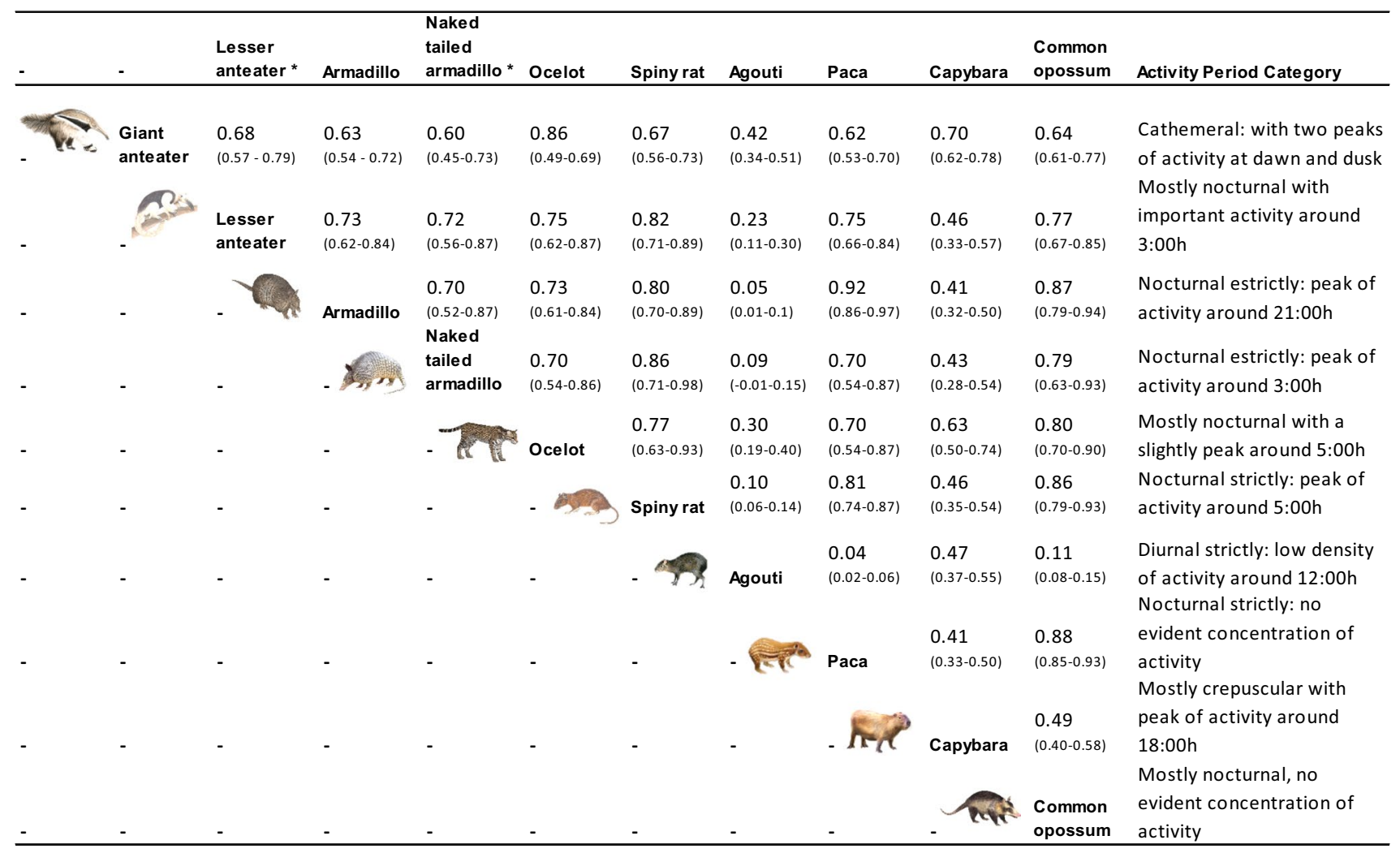

(i.e. less active during daytime), but in both habitats, this species avoided midday hours (i.e. very low activity to no activity).

\section{Do species modify their activity patterns between habitats?}

Given small capture rates in the majority of species, it was only possible to analyse changes in activity patterns between habitat types for four species ( $n>20$ in both habitats): capybara, giant anteaters, lesser anteaters and common opossums, with only the capybara showing a shift in activity patterns between habitats. Overlap estimation between habitats was not possible for some species such as the white-tailed deer, jaguarundi, or ocelot despite being present in both habitats, due to low records in either of the habitats (Table 1). For these species, though, activity patterns densities are shown for the habitat with more reliable data in Fig. 2. Since foxes, clearly preferred oil palm, it was not possible to test whether its activity patterns differed significantly between oil palm and riparian forest. Ocelots showed a clear nocturnal activity with only a few records during the daytime. It is worth noting, though, that all 15 records of ocelots inside oil palm plantations were only at night time (from 1800 to $0600 \mathrm{~h}$ ).
Capybaras had an overlap value of $0.32(0.22-0.40)$ and showed clear peaks of activity for each land cover. In the riparian forest, there was one peak at approximately $0500 \mathrm{~h}$ and another peak around $1800 \mathrm{~h}$, indicating crepuscular behaviour. In oil palm, however, while again there were two peaks of activity, these were centred at around $0300 \mathrm{~h}$ and at approximately $2100 \mathrm{~h}$, which indicates more nocturnal behaviour inside oil palm (Fig. 1). Capybaras were never detected after $\sim 0700 \mathrm{~h}$ in oil palm plantations. In contrast, giant anteaters, lesser anteaters, and common opossums (Didelphis marsupialis) showed an overlap of activities greater than 0.80 (Fig. 2), suggesting no major changes or modification of activity patterns between land cover types for these species. Giant anteaters showed an important decline in activities after $0600 \mathrm{~h}$ inside oil palm when their activity in forests tended to increase. Activities in oil palm remained low until $1700 \mathrm{~h}$ when they increased again showing a peak around $0100 \mathrm{~h}$. In the forest, the giant anteaters had two evident peaks of activities at crepuscular times (dawn and dusk). 


\section{Do species inside oil palm avoid times of high human activity?}

Only four species were suitable for this analysis (giant anteater, white-tailed deer, capybara, jaguarundi). Giant anteater appeared to avoid human activities when using oil palm plantations with an overlap value of just 0.27 (CI 0.19-0.33). Similarly, white-tailed deer register an overlap of $0.36(0.17-0.53)$, with a clear peak after human activities cease at $1800 \mathrm{~h}$ (Fig. 3). Capybaras had the lowest overlap with humans due to its markedly nocturnal behaviour inside oil palm $[\widehat{\Delta}=0.13(0.02-0.19)]$. In total contrast, jaguarundi displayed high overlaps with human activities $[\widehat{\Delta}=0.86(0.80-0.96)$, Fig. 3$]$, with a peak activity around midday.
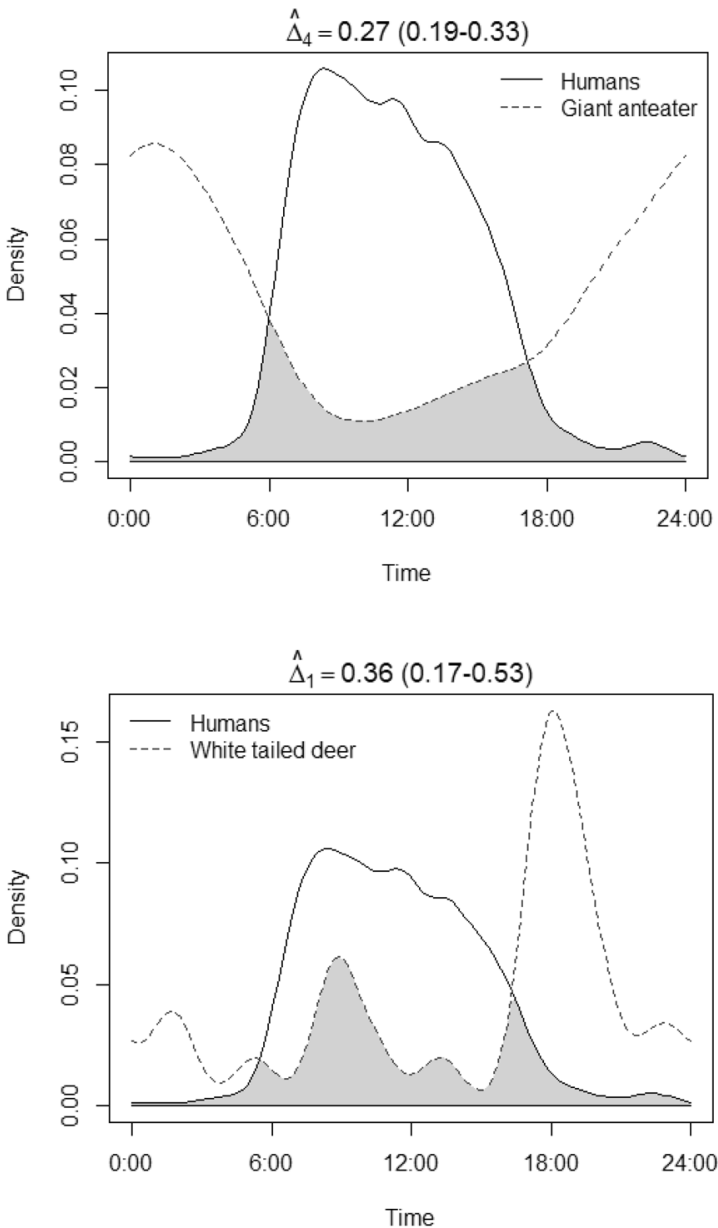

Fig. 3 Activity patterns and overlap coefficient estimate $(\widehat{\Delta})$ based on Kernel density function estimates between humans and giant anteater, and humans and jaguarundi inside oil palm plantations in the Llanos

\section{How do species-specific temporal interactions differ between habitats?}

\section{Interspecific interaction within the forest}

The greatest overlap of activity patterns between species was $0.92(0.86-0.97)$ between pacas and ninebanded armadillo, the least overlap was 0.05 (0.01-0.1), between agoutis and nine-banded armadillo. Capybaras and giant anteaters were the only species with relatively high overlapping with the strictly diurnal agoutis $[\widehat{\Delta}=0.47$ $(0.37-0.55)$ and $\widehat{\Delta}=0.42(0.34-0.51)$, respectively], followed by ocelots with a low overlap of $0.30(0.19-0.40)$ (Table 2), reflecting their capacity to be active during the day or night times. Potential prey-predator relationships showed that ocelots and common opossum overlapped by $0.80(0.70-0.90)$, followed by ocelots and spiny rats
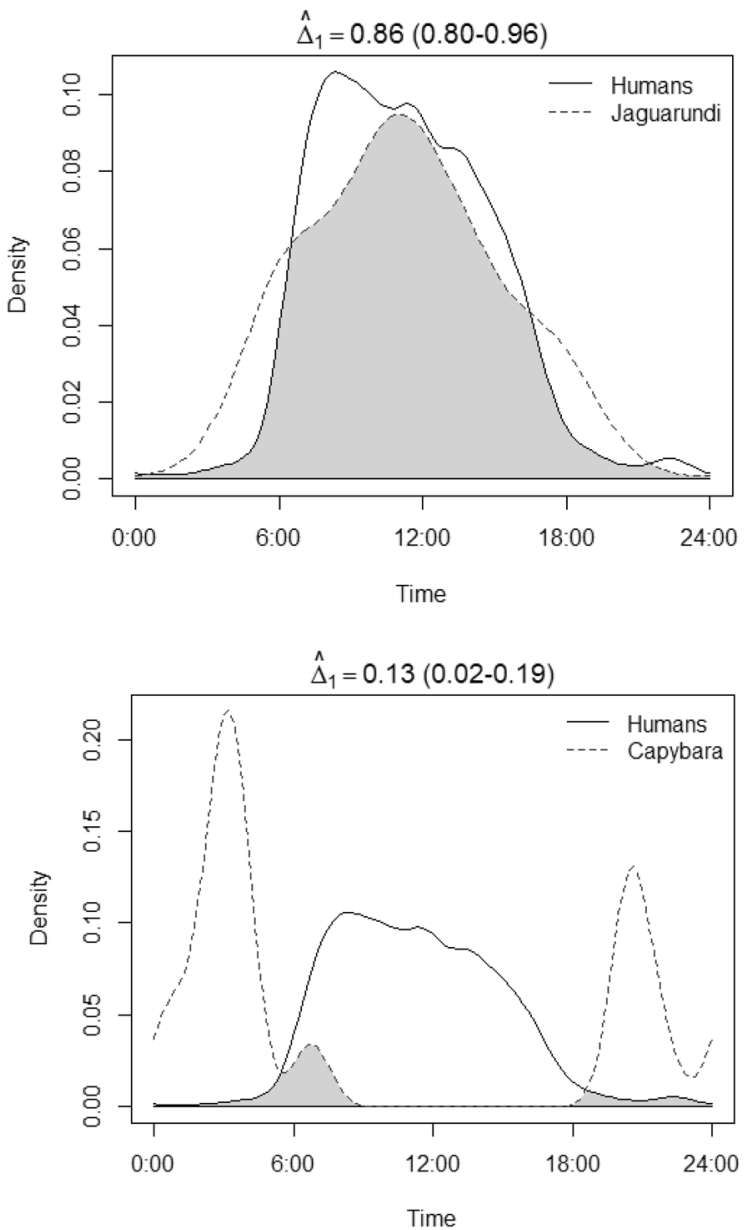

region of Colombia. Humans $(n=2344)$, giant anteater $(n=123)$, jaguarundi $(n=20)$, white-tailed deer $(n=22)$ and capybara $(n=29)$. Category "humans" include any independent photograph of workers and/or machinery (e.g. tractor, trucks) 
$[\widehat{\Delta}=0.77(0.63-0.93)]$, and nine-banded armadillo $[\widehat{\Delta}=$ $0.73(0.61-0.84)]$. Interestingly, both species of armadillos showed different peaks of activities with nine-banded armadillo being more active around $2100 \mathrm{~h}$ while nakedtailed armadillo around $0300 \mathrm{~h}$.

\section{Interspecific interaction within oil palm}

The highest interspecific overlap for species inside oil palm plantations was $0.90(0.79-0.99)$ between lesser anteaters and giant anteaters, the lowest overlap was estimated between jaguarundi and capybara, due to jaguarundi's marked diurnality $[\widehat{\Delta}=0.16(0.01-0.30)$ (Table 3$)$, followed by the jaguarundi and common opossum [ $\widehat{\Delta}$ $=0.24(0.07-0.39)]$. The most common overlap among species was $0.4-0.5$. The two most frequently photographed mesopredators inside oil palm plantation (foxes and jaguarundi) had an overlap value of 0.27 (0.14-0.44), suggesting temporal segregation in their activity patterns, with foxes being notably nocturnal. Overlap between the activity patterns of giant anteaters and lesser anteaters inside oil palm was greater than inside forests (i.e. $\widehat{\Delta}=$ $0.90(0.79-0.99)$ and $\widehat{\Delta}=0.68(0.57-0.79)$, respectively)

(Tables 2, 3).

\section{Discussion}

Overall, most species in the study area were primarily nocturnal, except for agouti and jaguarundi that were diurnal, and white-tailed deer and capybara that tended to be crepuscular (in oil palm and forest, respectively). Giant anteater had a cathemeral pattern, although activities were higher at crepuscular and nocturnal times. These results are not unexpected based on the biology and evolutionary history of Neotropical mammals (e.g. Blake et al. 2012; Eisenberg and Redford 1999; Emmons 1999; Ramírez-Mejía and Sánchez 2016).

\section{Effect of habitat and human activities}

Most species (for which we had sufficient data to assess overlap) showed no evidence to suggest that activity patterns were modified to enable persistence in oil palm plantations. However, we found evidence that capybaras, white-tailed deer, and giant anteaters tended to modify their behavioural patterns (compared to forest) to avoid human activities inside plantations by becoming more nocturnal (capybara and giant anteater) or more active at dusk (whitetailed deer). This tendency to increase nocturnality has been identified in other mammals around the world (Gaynor et al.

Table 3 Overlapping coefficient estimate $(\widehat{\Delta})$ based on Kernel density function estimates between selected species pairs inside oil palm and corresponding activity period categories across oil palm dominated landscapes in the Llanos region, Colombia

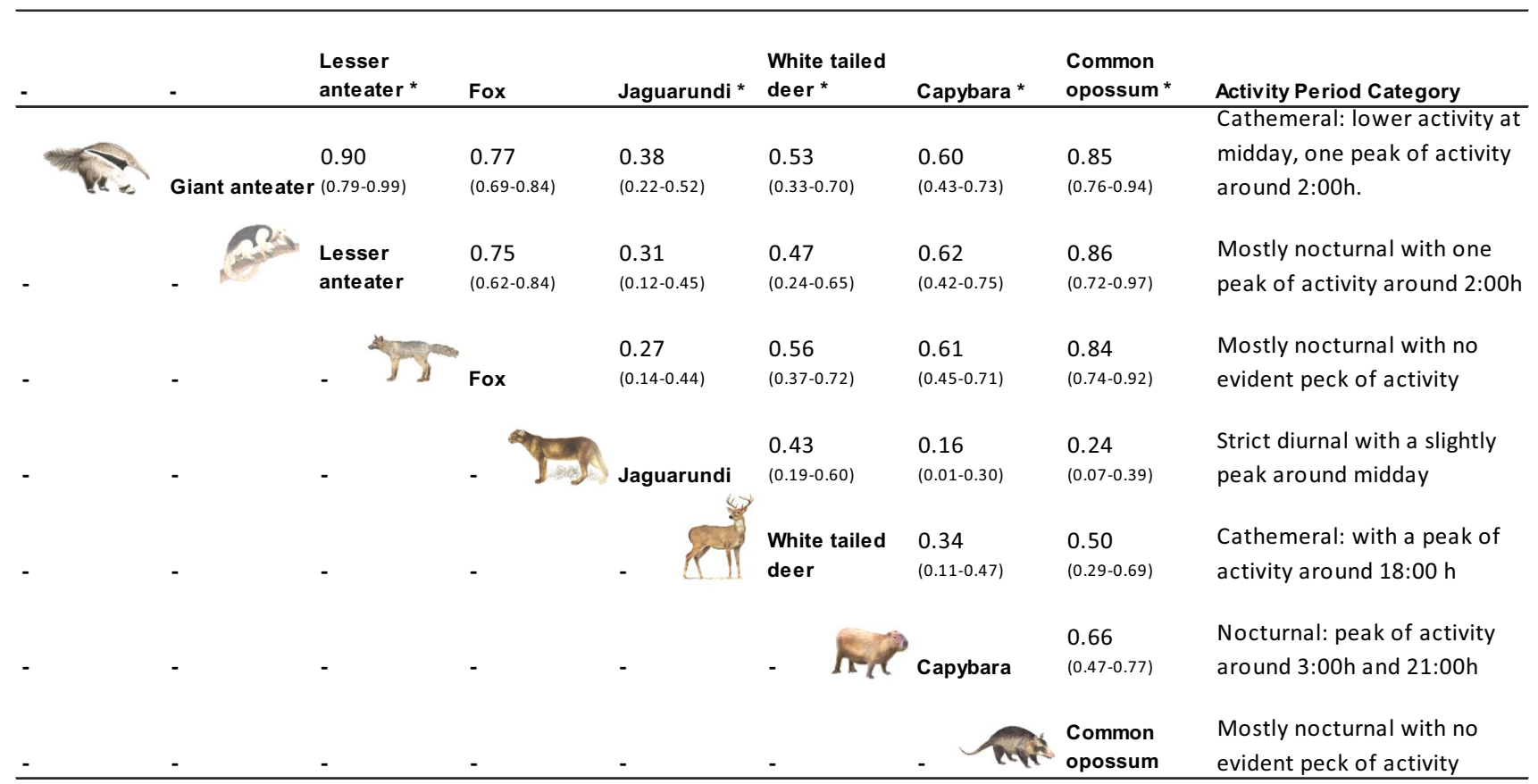

*Activity period categories: (1) diurnal $(6: 00-18: 00 \mathrm{~h})$, (2) nocturnal (18:00-6:00 h) and (3) crepuscular when most of the records were between 5:00 and 6:00 $\mathrm{h}$ (dawn) and 17:00-18:00 h (for dusk) (modified from van Schaik and Griffiths 1996) 
2018). Although not confirmed by overlap analysis, due to limited detections inside oil palm, it seemed that ocelots also tended to modify their schedule when using oil palm by becoming more nocturnal. There is evidence, however, that other carnivores, such as pumas (Puma concolor), bobcats (Lynx rufus), coyotes (Canis latrans) and servals (Leptailurus serval; an African felid with a similar niche as ocelots) reduce diurnal activities and increase nocturnal activity in locations associated with high human activity (Ramesh and Downs 2013; Wang et al. 2015). Therefore, further research would confirm whether ocelots also increase nocturnality in human-dominated lands.

The behavioural plasticity of some species supports previous findings suggesting that activity patterns could be modified in response to the environmental and human disturbances (e.g. Norris et al. 2010; Presley et al. 2009; Wong and Candolin 2015). Our findings for few species confirm that one way to adapt to oil palm habitats is through the modification of their activity patterns inside plantations. The giant anteater, in particular, appeared to be the most plastic of species in the western Llanos (see also Pardo et al. 2018a, 2019). Interestingly, in more conserved landscapes such as the Ecuadorian Amazonia giant anteater seem to be entirely diurnal (Blake et al. 2012), confirming the plasticity of this species. It is important to note that although the activity patterns of giant anteater inside oil palm was less diurnal compared to forest, the species tended to avoid peak daytimes in both land covers. Therefore, the lack of overlap with humans is influenced by their natural tendency to avoid times around midday, regardless of humans. A study of co-occupancy between humans and giant anteater would confirm if a spatial segregation is more important to avoid humans than temporal segregation.

Capybaras are the biggest grazing rodent in the Neotropics (Emmons 1999). In the Amazonia, they are suggested to be cathemeral (Gómez et al. 2005), while in natural savannas, they usually spend considerable time grazing in the evening (Camargo-Sanabria et al. 2014; Herrera and Macdonald 1989). Most natural savannas in the study area have been cleared for agriculture or cattle ranching (e.g. Etter et al. 2011). Probably, as a consequence, we only detected capybaras in $20 \%$ of the study area. This conversion of native grasslands to other land uses may have forced remaining populations of capybaras to use the grass that grows inside oil palm plantations (LEP pers. obs). Therefore, capybaras could have shifted their feeding times to avoid humans to be able to use the newly available resources inside oil palm.

The concentration of activities of white-tailed deer inside oil palm around dusk is unusual because previous reports suggest that this species display a crepuscular pattern of activity, with peaks in the morning and evening (e.g. López-Arévalo et al. 2020). Even in another oil palm plantation in the Llanos, Pardo et al. (2013) found two peaks at crepuscular times for this species, with activities in riparian forest concentrated around mid-day. This peak of activities for deer inside the plantations coincides with the end of daily working/harvesting activities inside plantation, which support the view that species prefer to be active when humans are not present. It is possible, for this and other species, that changes in activity patterns could also be influenced by other factors apart from human presence such as temperature (e.g. Di Blanco et al. 2017) Although the canopy inside plantations helps to reduce the temperature, this could be even lower inside riparian forest, which might influence some species to become more active inside forest when day temperature is highest. For example, the giant ant eater showed a broader range of active hours inside the forest.

Our results indicate that agoutis and pacas were strictly diurnal and nocturnal, respectively, similar to other studies in the Neotropics (Blake et al. 2012). However, previous findings in the Amazon region have shown that these species can also be found active outside these periods in more intact areas, though rarely (Gómez et al. 2005; Norris et al. 2010). We did not detect agoutis in plantations and pacas had only a single detection in this land cover (near to the forest), limiting the ability to make comparisons between them. However, this suggests that oil palm plantations are not a suitable habitat for agouti and paca (see Mendes-Oliveira et al. 2017; Pardo et al. 2018a), and are highly restricted in their capacity to adapt to changes on forested ecosystems to oil palm.

The lack of "fear" of people found for jaguarundi inside oil palm has been registered in other wild animals that can take advantage of novel environments and resources (e.g. organic waste, food, protection)(Lowry et al., 2013; Samia et al., 2015). A learning process in which larger species, such as the jaguarundi, eventually learn that people are not threatening can be related to the finding as suggested by (Samia et al. (2015). Apparently, jaguarundi is not of interest for hunters in the Llanos region, contrary to giant anteaters, ocelots, capybaras or deer which are persecuted or hunted in some areas (e.g. Usma and Trujillo, 2011, LEP pers. obs.). This could be a possible reason for their fear and tendency to avoid humans.

Contrary to ocelots, jaguarundis were strictly diurnal, as found by previous studies (Di Bitetti et al. 2010; Giordano 2016). This species showed a behavioural pattern opposite to ocelots, with less independent detections inside forests (see Pardo et al. 2018a), which limited the comparison of activities in both habitat types through the overlap coefficient. However, the six records of jaguarundi inside forests suggest no shifts in activity patterns between oil palm and forests (i.e. all detections were also during the day time). These clear differences in the activity patterns of jaguarundi and ocelots support the idea of temporal and spatial segregation, which has been suggested as a way to minimize competition among mesocarnivores (e.g. Di Bitetti et al. 2010, 
Monterroso et al. 2014). In this sense, it is likely that ocelots and jaguarundi exhibit avoidance in space (depending on habitats) and time in the study area, with ocelots preferring forests and night time and jaguarundi preferring oil palm plantations and diurnal activities. This dual avoidance (in space and time) has been described for other carnivores such as cheetahs (Acinonyx jubatus) regarding interactions with lions (Panthera leo) and hyenas (Crocuta crocuta) (Durant 1998). This avoidance is likely due to similarities in diet, which has been reported to be approximately $60 \%$ for both jaguarundi and ocelots-in the Mata Atlantica (Rocha et al. 2010). These behavioural adaptations have important positive effects in terms of fitness by reducing the effects of competition (Di Bitetti et al. 2010; Oliveira et al. 2010). The daily activity of ocelots in the riparian forest also coincides with other felids of similar sizes such as the clouded leopard (Neofelis nebulosa) in secondary forest surrounding oil palm plantations in Peninsular Malaysia (Azlan and Sharma 2006).

The broad niche and the evident differences found in the activity patterns between jaguarundi and ocelots (with the former being diurnal as opposed to the nocturnal preference of ocelot) may indicate that these species specialize in different prey (see Oliveira-Santos et al. 2008). In this sense, jaguarundi could have specialized in preying on reptiles (particularly Squamata) and birds (nest) that are also active during the day (e.g. Tófoli et al. 2009), whereas ocelots may have specialized in small nocturnal mammals such as rodents, opossums, or nine-banded armadillos (de Oliveira et al. 2010), as can be inferred from the overlapping value for these species within the riparian forest $(\widehat{\Delta}>0.70)$. Jaguarundi is known to be a highly generalist species within the carnivore guild with their diet including even snakes, and tegu lizards (Tupinambis spp) (Tófoli et al. 2009), two common reptiles species found within oil palm plantations (LEP pers. obs., Lynch 2015). Further investigation on the diet of these mesopredators would be important to confirm this hypothesis.

\section{Temporal interactions in the assemblage within each land cover type}

We identified some patterns when comparing the overlap values for the species between oil palm and forest. Giant and lesser anteater had lower overlapping of activity patterns inside forests, which could be related to differences in niche preferences. Although both species have similar diets, lesser anteaters can also exploit resources in the canopy, whereas giant anteaters specialize in soil communities (Gallo et al. 2017). Since oil palm plantations offer only one niche (i.e. soil ants and termites LEP Pers. obs.), and both species preferred nocturnal activities, it is expected that they could be active at similar hours. Conversely, the possibility of having another niche to forage inside forests could help reducing temporal overlapping by spatial niche segregation.

Inside oil palm, overlapping between foxes and jaguarundis (the two main predators) was low, indicating a temporal segregation strategy as described for jaguarundi and ocelot. However, the fox was the most frequently detected species inside oil palm. Given that mesopredators can play important roles in ecosystems, with positive and negative effects (see Crooks and Soulé 1999; Roemer et al. 2009), it is important to study the trophic relationships that have been promoted within oil palm landscapes and the potential effects that mesopredators may have in the long-term on other native species, particularly the high frequency of detection of foxes (see Pardo et al. 2018a).

Differences in activity patterns analysed through overlap coefficient estimation have been used as a proxy to assess species avoidance or segregation in predator-prey relationships (e.g. Halle 2006; Weckel et al. 2006; Ridout and Linkie 2009). However, conclusions about potential interactions between predators and prey should be drawn carefully in the absence of spatial or dietary assessments (Meredith and Ridout 2017; Weckel et al. 2006). Depending on some circumstances, an overlap in activity patterns does not necessarily imply a cause-effect relationship, nor equates to an overlap in space. As such, high overlapping does not always mean high direct interaction between individuals (in time and space), and low overlapping does not always account as avoidance (e.g. Díaz-Ruiz et al. 2016; Meredith and Ridout 2017). Nonetheless, predator-prey relationships have demonstrated synchronization between activity periods (e.g. Halle 2006; Lima 2002; Linkie and Ridout 2011; Lucherini et al. 2009; Weckel et al. 2006). Therefore, our findings give insights into likely predator-prey relationships, and into the general ecology of terrestrial mammals in Colombia, a field that has been poorly documented. Few studies in the Neotropics have assessed possible temporal interactions among species, and only Brazil, Ecuador and Bolivia have carried out most of the research (Maffei et al. 2002; Gómez et al. 2005; Oliveira et al. 2010; Blake et al. 2012). We acknowledge there could be other interacting factors not assessed in this study that could have also influenced the patterns described for the study area. For example, some plantations have different varieties of palms that produce denser canopies, which, therefore, could reduce day temperatures and could probably promote species to be more active during hot days. Similarly, the limited data restrain us from making inference to the whole assemblage, and results should be interpreted by species. 


\section{Conclusions}

To our knowledge, this is the first study aimed to evaluate the influence of industrial agriculture on behavioural responses of mammal species in Colombia. Overall, we found no substantial differences in activity patterns between oil palm plantations and riparian forest (i.e. no modification given presence of oil palm), except for capybaras, which tended to modify their activities inside plantations, by becoming notably nocturnal. This species, as well as giant anteaters and deer tended to avoid humans when active inside oil palm. Interestingly jaguarundi, a relatively common diurnal species inside oil palm, did not show evidence of human avoidance. Our results provide evidence of mammalian temporal segregation as a mechanism to avoid interspecific competition in some common species, such as jaguarundi and fox, and a high overlap in potential predator-prey relationships (e.g. ocelots and armadillos). This study on behavioural responses contributes to the understanding of mammalian resilience in anthropogenic landscapes and the natural history of poorly known species. This is a feature of the effect of anthropogenic land use change not captured in traditional studies that focus on measures such as species richness or abundance. Further, this study complements the growing documentation aimed to understand biodiversity in oil palm landscapes in Colombia.

Funding Funding was provided by an Australian Laureate Fellowship from the Australian Research Council, awarded to Professor William F. Laurance (2010). The lead author also thanks COLCIENCIAS's postgraduate scholarship scheme Francisco José de Caldas, Colombia. Oil palm growers supported this research in kind including for example accommodation, food, travel expenses.

Availability of data and material Data will be store in a repository for public access once the paper is accepted.

Code availability Not applicable.

\section{Declarations}

Conflict of interest The authors declare no conflict of interest. All authors certify that they have no affiliations with or involvement in any organization or entity with any financial interest or non-financial interest in the subject matter or materials discussed in this manuscript.

Ethics approval Our research did not include any invasive technique that required handling or capture of live animals. Our methods were strictly based on camera traps, a non-invasive technique which, therefore, does not compromise the welfare of our study species. Our research followed corresponding protocols on this matter according to the Colombian regulations. Since our research did not require manipulation of any species or direct experimentation, this research did not require a revision or permission by an institutional or governmental regulatory body. However, in our research we strived to respect and acted ethically towards ecosystems and animals' welfare while conduct- ing our fieldwork. All permits to access private lands were also given before conducting the study in oil palm landscapes.

Consent to participate Not applicable, our research does not involve any informed consent from people. However, we did have the permissions from all landowners to conduct the study.

Consent for publication We authors have no conflict of interest and we are all agree to submit this manuscript to this journal. Although this research was conducted on private lands and agricultural companies, they did not impose any condition regarding publications and we were not tight to any consent or acceptance from them to submit this paper.

Open Access This article is licensed under a Creative Commons Attribution 4.0 International License, which permits use, sharing, adaptation, distribution and reproduction in any medium or format, as long as you give appropriate credit to the original author(s) and the source, provide a link to the Creative Commons licence, and indicate if changes were made. The images or other third party material in this article are included in the article's Creative Commons licence, unless indicated otherwise in a credit line to the material. If material is not included in the article's Creative Commons licence and your intended use is not permitted by statutory regulation or exceeds the permitted use, you will need to obtain permission directly from the copyright holder. To view a copy of this licence, visit http://creativecommons.org/licenses/by/4.0/.

\section{References}

Azhar B, Lindenmayer DB, Wood J, Fischer J, Zakaria M (2014) Ecological impacts of oil palm agriculture on forest mammals in plantation estates and smallholdings. Biodivers Conserv 23:11751191. https://doi.org/10.1007/s10531-014-0656-Z

Azlan JM, Sharma DSK (2006) The diversity and activity patterns of wild felids in a secondary forest in Peninsular Malaysia. Oryx 40:36-41. https://doi.org/10.1017/S0030605306000147

Blake JG, Mosquera D, Loiselle BA, Swing K, Guerra J, Romo D (2012) Temporal activity patterns of terrestrial mammals in lowland rainforest of Eastern Ecuador. Ecotropica 18:137-146

Burton AC, Neilson E, Moreira D, Ladle A, Steenweg R, Fisher JT, Bayne E, Boutin S (2015) Wildlife camera trapping: a review and recommendations for linking surveys to ecological processes. $\mathbf{J}$ Appl Ecol 52:675-685. https://doi.org/10.1111/1365-2664.12432

Caceres-Martínez CH, Acevedo Rincón AA, González-Maya JF (2016) Terrestrial medium and large-sized mammal's diversity and activity patterns from Tamá National Natural Park and buffer zone, Colombia. Therya 7:285-298. https://doi.org/10.12933/ therya-16-397

Camargo-Sanabria AA, Pardo LE, López-Arévalo H, Sanchez-Palomino P, Caro CI (2014) Área de acción y movimientos del chigüiro (Hydrochoerus hydrochaeris) en el municipio de Paz de Ariporo, Casanare, Colombia: Algunas consideraciones para su manejo. In: López-Arévalo HF, Sánchez-Palomino P, Montenégro $\mathrm{O}$ (eds) El Chigüiro Hydrochoerus Hydrochaeris En La Orinoquía Colombiana: Ecología, Manejo Sostenible y Conservación. Biblioteca José Jerónimo Triana No. 25. Instituto de Ciencias Naturales. Universidad Nacional de Colombia, Bogotá D.C., p 436

Crooks K, Soulé M (1999) Mesopredator release and avifaunal extinctions in a fragmented system. Nature 400:563-566. https://doi. org $/ 10.1038 / 23028$

de Oliveira TG, Tortato MA, Silveira L, Kasper CB, Mazim FD, Lucherini M, Jácobo AT, Soares JBG, Marquez RV, Sunquist ME (2010) Ocelot ecology and its effect on the small-felid guild in 
the lowland Neotropics. In: Macdonald DW, Loveridge AJ (eds) Biology and conservation of wild felids. Oxford University Press, New York, pp 559-580

Di Bitetti MS, Paviolo A, De Angelo C (2006) Density, habitat use and activity patterns of ocelots (Leopardus pardalis) in the Atlantic Forest of Misiones, Argentina. J Zool. https://doi.org/10.1111/j. 1469-7998.2006.00102.x

Di Bitetti MS, Paviolo A, Ferrari CA, De Angelo C, Di Blanco Y (2008) Differential responses to hunting in two sympatric species of brocket deer (Mazama americana) and M. nana). Biotropica 40:636-645. https://doi.org/10.1111/j.1744-7429.2008.00413.x

Di Bitetti MS, De Angelo CD, Di Blanco YE, Paviolo A (2010) Niche partitioning and species coexistence in a Neotropical felid assemblage. Acta Oecol 36:403-412. https://doi.org/10.1016/j.actao. 2010.04.001

Di Blanco YE, Spørring KL, Di Bitetti MS (2017) Daily activity pattern of reintroduced giant anteaters (Myrmecophaga tridactyla): effects of seasonality and experience. Mammalia 81:11-21. https://doi.org/10.1515/mammalia-2015-0088

Díaz-Pulido A, Abud M, Alviz Á, Arias A, Aya C, Benítez A, Bonilla A, Botero S, Bravo E, Calero H, Acevedo M, Duque JS, Fernández C, Forero-Medina G, Galeano A, Garcia S, Goméz D, Jose FG-M, Hernández V, Cabrera A, López-Arévalo H, López JP, Marín D, Mazabe E, Monsalve S, Olarte G, Pardo LE, Payan E, Pérez K, Quintana R, Reyes A, Rodriguez-Posada M, Rojano C, Salazar E, Solari S, Soto C, Stasiukynas D, Suárez G, Valderrama C, Valderrama S, Valencia-Mazo D, Valenzuela L, Vela M, Zarrate-Charry D (2017) Fototrampeo. In: Moreno LA, Andrade GI, Ruíz- Contreras LF (eds) Biodiversidad 2016. Estado y Tendencias de La Biodiversidad Continental de Colombia. Instituto de Investigación de Recursos Biológicos Alexander von Humboldt, Bogotá D.C., Colombia, p 15

Díaz-Ruiz F, Caro J, Delibes-Mateos M, Arroyo B, Ferreras P (2016) Drivers of red fox (Vulpes vulpes ) daily activity: prey availability, human disturbance or habitat structure? J Zool 298:128-138. https://doi.org/10.1111/jzo.12294

Durant SM (1998) Competition refuges and coexistence: an example from Serengeti carnivores. J Anim Ecol 67:370-386. https://doi. org/10.1046/j.1365-2656.1998.00202.x

Eisenberg JF, Redford KH (1999) Mammals of the neotropics: the Central Neotropics, vol 3. The University of Chicago Press, Chicago

Emmons LH (1999) Mamíferos de los bosques húmedos de América Tropical. Una guia de campo, 2nd edn. FAN, Santa Cruz

Fedepalma (2019) Anuario Estadístico 2019: Principales cifras de agroindustria de la palma de aceite en Colombia 2014-2018. Fedepalma, Bogotá D.C., Colombia

Etter A, Sarmiento A, Romero MH (2011) Land use changes (19702020) and carbon emissions in the Colombian Llanos. In: Hill MJ, Hanan NP (eds) Ecosystem function in Savannas. Measurements and modelling at landscape to global scales. CRC Press, New York, pp 383-402

Ferrer A, Beltrán M, Díaz-Pulido A, Trujillo F, Mantilla-Meluk H, Herrera O, Alfonso A, Payan E (2009) Lista de los mamíferos de la cuenca del río Orinoco. Biota Colomb 10:179-207

Fitzherbert EB, Struebig MJ, Morel A, Danielsen F, Brühl CA, Donald PF, Phalan B (2008) How will oil palm expansion affect biodiversity? Trends Ecol Evol 23:538-545. https://doi.org/10.1016/j. tree.2008.06.012

Foster VC, Sarmento P, Sollmann R, Tôrres N, Jácomo ATA, Negrões N, Fonseca C, Silveira L (2013) Jaguar and Puma activity patterns and predator-prey interactions in four brazilian biomes. Biotropica 45:373-379. https://doi.org/10.1111/btp.12021

Furumo PR, Aide TM (2017) Characterizing commercial oil palm expansion in Latin America: land use change and trade. Environ Res Lett 12:024008. https://doi.org/10.1088/1748-9326/aa5892
Gallo JA., Abba AM, Elizalde L, Di Nucci D, Ríos TA, Ezquiaga MC (2017) First study on food habits of anteaters, Myrmecophaga tridactyla and Tamandua tetradactyla, at the southern limit of their distribution. Mammalia 81:601-604. https://doi.org/10.1515/ mammalia-2016-0117

Gaynor KM, Hojnowski CE, Carter NH, Brashares JS (2018) The influence of human disturbance on wildlife nocturnality. Science. https://doi.org/10.1126/science.aar7121

Gilroy JJ, Prescott GW, Cardenas JS, Castañeda PGDP, Sánchez A, Rojas-Murcia LE, Medina-Uribe CA, Haugaasen T, Edwards DP (2015) Minimizing the biodiversity impact of Neotropical oil palm development. Glob Chang Biol 21:1531-1540. https://doi.org/10. $1111 / \mathrm{gcb} .12696$

Giordano AJ (2016) Ecology and status of the jaguarundi Puma yagouaroundi: a synthesis of existing knowledge. Mamm Rev 46:3043. https://doi.org/10.1111/mam.12051

Gómez H, Wallace RB, Ayala G, Tejada R (2005) Dry season activity periods of some Amazonian mammals. Stud Neotrop Fauna Environ 40:91-95. https://doi.org/10.1080/01650520500129638

González-Maya JF, Schipper J, Benítez A (2009) Activity patterns and community ecology of small carnivores in the Talamanca region. Costa Rica Small Carniv Conserv 41:9-14

González-Maya JF, Zárrate-Charry D, Vela-Vargas IM, JiménezAlvarado JS, Gómez-Hoyos D (201) Activity patterns of Tayra Eira barbara populations from Costa Rica and Colombi: evidence of seasonal effects Patrones de actividad de poblaciones de la Tayra Eira barbara en Costa Rica y Colombia: evidencia de efectos estacionales. Rev Biodivers Neotrop 5:96-104. https:// doi.org/10.1863/REBIONEO2JD20152

Halle S (2000) Ecological relevance of daily activity patterns. In: Halle S, Stenseth NC (eds) Activity patterns in small mammals: an ecological approach. Springer, New York, pp 67-90

Halle S (2006) Polyphasic activity patterns in small mammals. Folia Primatol 77:15-26. https://doi.org/10.1159/000089693

Herrera EA, Macdonald DW (1989) Resource utilization and territoriality in group-living capybaras (Hydrochoerus hydrochaeris). J Anim Ecol 58:667. https://doi.org/10.2307/4855

IDEAM, IGAC, IAvH, Invemar, Sinchi I, IIAP (2007) Ecosistemas continentales, costeros y marinos de Colombia. ed. Instituto Geográfico Agustín Codazzi (IGAC), Bogotá D.C., Colombia

Lasso CA, Rial A, Matallana Ramírez W, Señaris J, Díaz-Pulido A, Corzo G, Machado-Allison A (eds) (2011) Biodiversidad de la cuenca del Orinoco. II Áreas prioritarias para la conservación y uso sostenible. Instituto de Investigación de Recursos Biológicos Alexander von Humboldt, Ministerio del Ambiente, Vivienda y Desarrollo Territorial, WWF Colombia, Fundación Omacha, Fundación La Salle de Ciencias Naturales e Instituto de Estudios de la Orinoquia, Univers, Bogotá

Lima SL (2002) Putting predators back into behavioral predatorprey interactions. Trends Ecol Evol 17:70-75. https://doi.org/ 10.1016/S0169-5347(01)02393-X

Linkie M, Ridout MS (2011) Assessing tiger-prey interactions in Sumatran rainforests. J Zoo 284:224-229. https://doi.org/10. 1111/j.1469-7998.2011.00801.x

López-Arévalo HF, Pardo LE, Pérez-Moreno H (2020) Generalidades de la especie. In: Ecología, Uso, Manejo y Conservación Del Venado Cola Blanca En Colombia. Biblioteca José Jerónimo Triana N. ${ }^{\circ} 33$. Instituto de Ciencias Naturales, Universidad Nacional de Colombia, Bogotá D,C., pp 19-30

López-Ricaurte L, Edwards DP, Romero-Rodríguez N, Gilroy J (2017) Impacts of oil palm expansion on avian biodiversity in a Neotropical natural savanna. Biol Conserv 213:225-233. https:// doi.org/10.1016/j.biocon.2017.07.009

Lowry H, Lill A, Wong BBM (2013) Behavioural responses of wildlife to urban environments. Biol Rev 88:537-549. https://doi. org/10.1111/brv.12012 
Lucherini M, Reppucci JI, Vidal EL (2009) A comparison of three methods to estimate variation in the relative abundance of mountain vizcachas (Lagidium viscacia) in the High Andes ecosystems. Mastozoología Neotropical, vol 16, issue 1, enerojunio, 2009, pp 223-228

Lynch JD (2015) The role of plantations of the African palm (Elaeis guineensis JacQ.) in the conservation of snakes in Colombia. Caldasia 37:169-182

Maffei L, Cuéllar E, Noss, A (2002) Using Camera-Traps To Asses Mammals in the Chaco- Chiquitano Ecotone. Bol. Ecol 11:55-65

Maffei L, Noss AJ, Cuéllar E, Rumiz DI (2005) Ocelot (Felis pardalis) population densities, activity, and ranging behaviour in the dry forests of eastern Bolivia: data from camera trapping. J Trop Ecol 21:349-353. https://doi.org/10.1017/S0266467405002397

Mendes-Oliveira AC, Peres CA, Maués PCR, de Oliveira AGL, Mineiro IGB, de Maria SLS, Lima RCS (2017) Oil palm monoculture induces drastic erosion of an Amazonian forest mammal fauna. PLoS ONE. https://doi.org/10.1371/journal.pone.01876 50

Meredith M, Ridout M (2017) Overview of the overlap package. Available from https://cran.r-project.org/web/packages/overlap/ vignettes/overlap.pdf

Monterroso P, Alves PC, Ferreras P (2014) Plasticity in circadian activity patterns of mesocarnivores in Southwestern Europe : implications for species coexistence. Behav. Ecol. Sociobiol. 68:14031417. https://doi.org/10.1007/s00265-014-1748-1

Muñoz J, Betancur O, Duque M (2002) Patrones de hábitat y de actividad nocturna de Agouti paca en el Parque Nacional Natural Utría (Chocó, Colombia). Actual Biológicas 24:75-85

Norris D, Michalski F, Peres CA (2010) Habitat patch size modulates terrestrial mammal activity patterns in Amazonian forest fragments. J Mammal 91:551-560. https://doi.org/10.1644/ 09-MAMM-A-199.1

O’Brien TG, Kinnaird MF, Wibisono HT (2003) Crouching tigers, hidden prey: Sumatran tiger and prey populations in a tropical forest landscape. Anim Conserv 6:131-139. https://doi.org/10. 1017/S1367943003003172

Oliveira-Santos LGR, Tortato MA, Graipel ME (2008) Activity pattern of Atlantic Forest small arboreal mammals as revealed by camera traps. J Trop Ecol 24:563-567. https://doi.org/10.1017/ S0266467408005324

Pardo LE, Ocampo-Peñuela N (2019) Contexto actual del impacto ambiental de la palma de aceite en Colombia. Palmas 40:79-88

Pardo LE, Payán E (2015) Mamíferos de un agropaisaje de palma de aceite en las sabanas inundables de Orocué, Casanare. Colombia Biota Colomb 16:54-66

Pardo LE, Antelo R, Amezquita A, Soto C, Payán E (2013) Vertebrados de Altamira. Un informe para lograr la coexistencia de grandes vertebrados en el agropaisaje llanero. Fundación Panthera, Fundación Palmarito, Bogotá D.C.

Pardo LE, Laurance WF, Clements GR, Edwards W (2015) The impacts of oil palm agriculture on Colombia's biodiversity: what we know and still need to know. Trop Conserv Sci 88:828-845. https://doi.org/10.1177/194008291500800317

Pardo LE, Cove MV, Spinola RM, de la Cruz JC, Saenz JC (2016) Assessing species traits and landscape relationships of the mammalian carnivore community in a neotropical biological corridor. Biodivers Conserv 25:739-752. https://doi.org/10.1007/ s10531-016-1089-7

Pardo LE, Campbell MJ, Edwards W, Clements GR, Laurance WF (2018a) Terrestrial mammal responses to oil palm dominated landscapes in Colombia. PLoS ONE 13:e0197539. https://doi. org/10.1371/journal.pone.0197539

Pardo LE, de Roque OF, Campbell MJ, Younes N, Edwards W, Laurance WF (2018b) Identifying critical limits in oil palm cover for the conservation of terrestrial mammals in Colombia. Biol
Conserv 227:65-73. https://doi.org/10.1016/J.BIOCON.2018. 08.026

Pardo LE, Campbell MJ, Cove MV, Edwards W, Clements GR, Laurance WF (2019) Land management strategies can increase oil palm plantation use by some terrestrial mammals in Colombia. Sci Rep 9:7812. https://doi.org/10.1038/s41598-019-44288-y

Prescott GW, Gilroy JJ, Haugaasen T, Medina-Uribe CA, Foster WA, Edwards DP (2016) Reducing the impacts of Neotropical oil palm development on functional diversity. Biol Conserv 197:139-145. https://doi.org/10.1016/j.biocon.2016.02.013

Presley SJ, Willig MR, Castro-Arellano I, Weaver SC (2009) Effects of habitat conversion on temporal activity patterns of phyllostomid bats in Lowland Amazonian rain forest. J Mammal 90:210-221. https://doi.org/10.1644/08-MAMM-A-089.1

R Development Core Team (2014) R: a language and environment for statistical computing. R Foundation for Statistical Computing. Viena, Austria

Ramesh T, Downs CT (2013) Impact of farmland use on population density and activity patterns of serval in South Africa. J Mammal 94:1460-1470

Ramírez-Cháves H, Suárez-Castro A, González-Maya JF (2016) Cambios recientes a la lista de los mamíferos de Colombia. Notas Mastozoológicas 3:1-20

Ramírez-Mejía AF, Sánchez F (2016) Activity patterns and habitat use of mammals in an Andean forest and a Eucalyptus reforestation in Colombia. Hystrix Ital J Mammal. https://doi.org/10.4404/hystr ix-27.2-113199

Ridout MS, Linkie M (2009) Estimating overlap of daily activity patterns from camera trap data. J Agric Biol Environ Stat 14:322337. https://doi.org/10.1198/jabes.2009.08038

Rocha-Mendes F, Mikich SB, Quadros J, Pedro WA (2010) Feeding ecology of carnivores (Mammalia, Carnivora) in Atlantic Forest remnants, Southern Brazil. Biota Neotrop. 10:21-30. https://doi. org/10.1590/S1676-06032010000400001

Roemer GW, Gompper ME, Van Valkenburgh B (2009) The ecological role of the mammalian Mesocarnivore. Bioscience 59:165-173. https://doi.org/10.1525/bio.2009.59.2.9

Rovero F, Martin E, Rosa M, Ahumada JA, Spitale D (2014) Estimating species richness and modelling habitat preferences of tropical forest mammals from camera trap data. PLoS ONE. https://doi. org/10.1371/journal.pone. 0103300

Samia DSM, Nakagawa S, Nomura F, Rangel TF, Blumstein DT (2015) Increased tolerance to humans among disturbed wildlife. Nat Commun 6:8877. https://doi.org/10.1038/ncomms9877

Sih A, Ferrari MCO, Harris DJ (2011) Evolution and behavioural responses to human-induced rapid environmental change. Evol Appl 4:367-387. https://doi.org/10.1111/j.1752-4571.2010. 00166.x

Silveira L, Jácomo ATA, Diniz-Filho JAF (2003) Camera trap, line transect census and track surveys: a comparative evaluation. Biol Conserv 114:351-355. https://doi.org/10.1016/S0006-3207(03) 00063-6

Team Network (2008) Terrestrial vertebrate protocol implementation manual, v. 3.0. Tropical Ecology, Assessment and Monitoring Network, Center for Applied Biodiversity Science, Conservation International, Arlington, USA

Tobler MW, Carrillo-Percastegui SE, Leite Pitman R, Mares R, Powell $G$ (2008) An evaluation of camera traps for inventorying largeand medium-sized terrestrial rainforest mammals. Anim Conserv 11:169-178. https://doi.org/10.1111/j.1469-1795.2008.00169.x

Tófoli C, Rohe F, Setz E (2009) Jaguarundi (Puma yagouaroundi) (Geoffroy, 1803) (Carnivora, Felidae) food habits in a mosaic of Atlantic Rainforest and eucalypt plantations of southeastern Brazil. Braz J Biol 69:871-877 
Usma J, Trujillo F (2011) Biodiversidad del Departamento del Casanare: identificación de ecosistemas estratégicos. Gobernación del Casanare-WWF Colombia, Bogotá D.C., Colombia

van Schaik CP, Griffiths M (1996) Activity periods of Indonesian rain forest mammals. Biotropica 28:105-112. https://doi.org/10.2307/ 2388775

Wang Y, Allen ML, Wilmers CC (2015) Mesopredator spatial and temporal responses to large predators and human development in the Santa Cruz Mountains of California. Biol Conserv 190:23-33. https://doi.org/10.1016/j.biocon.2015.05.007

Wearn OR, Rowcliffe JM, Carbone C, Pfeifer M, Bernard H, Ewers RM (2017) Mammalian species abundance across a gradient of tropical land-use intensity: a hierarchical multi-species modelling approach. Biol Conserv 212:162-171. https://doi.org/10.1016/J. BIOCON.2017.05.007

Weckel M, Giuliano W, Silver S (2006) Jaguar (Panthera onca) feeding ecology: Distribution of predator and prey through time and space. J Zool 270:25-30. https://doi.org/10.1111/j.1469-7998. 2006.00106.x

Wong BBM, Candolin U (2015) Behavioral responses to changing environments. Behav Ecol 26:665-673. https://doi.org/10.1093/ beheco/aru183

Yue S, Brodie JF, Zipkin EF, Bernard H (2015) Oil palm plantations fail to support mammal diversity. Eco 1 Appl 25:2285-2292. https://doi.org/10.1890/14-1928.1

Publisher's Note Springer Nature remains neutral with regard to jurisdictional claims in published maps and institutional affiliations. 